\title{
The History of Corporate Rescue in the UK
}

\author{
Mei Yang ${ }^{1} \&$ Xiaobing $\mathrm{Li}^{2}$ \\ ${ }^{1}$ School of Law, Renmin University of China, Beijing, China \\ ${ }^{2}$ Beijing UpRight Law Firm, Beijing, China \\ Correspondence: Mei Yang, School of Law, Renmin University of China, 59 Zhongguan Cun Street, Beijing \\ 100872, China. E-mail: ym_yangmei@hotmail.com
}

Received: March 23, 2012 Accepted: July 6, 2012 Online Published: October 18, 2012

doi:10.5539/ass.v8n13p21 URL: http://dx.doi.org/10.5539/ass.v8n13p21

\begin{abstract}
During the past few years rescue culture flourished in the world. Many countries recently experienced a process of legislative reform and development in relation to their corporate rescue legislation. All of them tried to provide more chance for a company to overcome their financial difficulties through legislation. It has been believed that "assets would be more highly valued if utilized in the industry for which they were designed, rather than scrapped." (Note 1) The Insolvency Act 1986 since it is applied had experienced a long history. However the effect of it in the area of corporate rescue is disappointed. The Enterprise Act 2002 marked a shift in direction for corporate insolvency law in the UK, which meant the UK had realized the weakness of the Insolvency Act 1986. This can be seen as the first step that the UK made to develop the rescue culture. However, this step is not long enough. In this article, firstly I will generally summarize the development of corporate rescue law in the Enterprise Act 2002. Then I will try to give my own proposal about what need to be further developed in the near future.
\end{abstract}

Keywords: corporate rescue, history, UK

\section{The Corporate Rescue Culture Developed in the Enterprise Act 2002}

Enterprise Act 2002 can be seen as a milestone in the UK rescue legislation. Its significance was reflected in many aspects, especially in the aspect of terminating floating charge holder's power to appoint an administrative receiver, providing the way to administration out of Court and abolishing Crown's preferential rights. In the following passage, firstly I will briefly introduce the changes contained in Enterprise Act 2002, especially on the three aspects I listed above. Then I will explain that considering the reality of the corporate rescue mechanism, further changes are in need.

\subsection{The Comparative Ease of Initiation}

In the new corporate rescue legislation, there will be three methods by which an administrator of a company may be appointed. (Note 2) (1) by the court making an administration order under para10; (2) by the holder of a qualifying floating charge under para14; (3) by the company or its directors under para22. The last two methods provided a way to administration without involvement of the Court. It also provided a better framework which made the administration can be widely used in the UK. The complexity of the system combined with the high cost of the procedure is always the main obstacle for small even medium companies to resort to rescue mechanism when they are in financial difficulties. (Note 3) "This new provision to some extent obviates some of the expense and delay that has been associated hitherto with obtaining an administration order." (Note 4)

In UK insolvency regime, frequent participation of the Court, either as a safeguard or as a decision maker, has made the UK rehabilitation proceeding very expensive. (Note 5) This new provision provided two easier and more efficient ways for initiation of the corporate rescue. Lower cost and simpler procedure will benefit the whole UK corporations especially small ones.

As I analyzed above this provision should be applauded. However, the problem about the high cost (both in money and in time) of the corporate rescue procedure is still existed in other aspects in the English rescue legislation. This problem will be explored further on in my proposal.

\subsection{Terminating the Powers of Floating Charge Holder to Appoint Administrative Receiver}

The Insolvency Act 1986 as the main legislation of Corporate Rescue in England has always been criticized for its extraordinary power to secured creditors. This has been thought to have prevented the further development of 
a rescue culture. After the commencement of the Enterprise Act 2002 the power to the holder of floating charge was largely abolished. Section 250 of the Enterprise Act inserts a new section $72 \mathrm{~A}$ into the Act. It provides that "the holder of a 'qualifying floating charge' may not appoint an administrative receiver." (Note 6) The meaning of this phrase is given in para 14 of the newly inserted Schedule B1.Although in the Enterprise Act 2002 the floating charge holder's power to appoint an administrative receiver was terminated, the concerns are still existed. In one aspect, the new provision did not restrict the powers of floating charge holders whose floating charge had been created prior to the commencement of the new provisions. (Note 7) A commentator ever concerned that "Given the vast amount of security already in existence, the days of new appointments should thus continue for quite some time to come." (Note8) During this period the existed floating charge holders will have two choices when a company is in financial difficulties. "They may appoint an administrative receiver under its existing rights or it may appoint an administrator under the new legislation." (Note9) How to encourage these floating charge holders to choose the second approach instead of the first one is the following problem which needs to be further considered by professionals and legislators. In another aspect, the powers of floating charge holders to appoint an administrative receiver still remained in certain cases. (Note10) Beyond that the new legislation did not make any changes to the general law concerning the powers and duties of administrative receivers, (Note11) which meant secured creditors' super priority that can certainly prevent rehabilitation will still affect the English rescue mechanism for some time. In my proposal I also try to give some suggestions to this problem.

\subsection{The Abolition of Crowns Preference}

The third important contribution of the Enterprise Act 2002 is that it abolished the Crowns preference. This change was important in the field of corporate rescue and also gave great influence to the field of insolvency.

In the new legislation the Crown lost its status as a preferential creditor which, under the 1986 Act, concerned debts due to the Crown for PAYE due by an employer or construction contractor, VAT and other duties payable to HM Customs \& Excise and social security contributions. (Note12) This change should be applauded. One important point is that the benefits flowing from the abolition of Crown preference go to unsecured creditors rather than to the holders of floating charges.

The success of the Enterprise Act 2002 was not only limited to the above three aspects. Due to the substance and limit of this article I cannot introduce every point in detail. In short the Enterprise Act 2002 greatly developed the rescue culture in the UK. However, in view of the effects of the corporate rehabilitation procedure in the UK now, we should realize that proposals should be given for further development. The most controversial point both in academic field and in practice is who should control the company when it is in financial difficulties. This is the main point I will discuss in my proposal. Following this issue is the problem about who should have the right to initiate the proposal and how to restrict the rights of the controllers. At last I will touch the core problem in the whole rescue proceedings--the availability of financing. Although different parties have proposed that there should be specific legislation about the availability of finance in the process of corporate rehabilitaion, (Note13) it was not emphasized in Enterprise Act 2002. In my proposal I will try to reiterate the significance of availability of finance in the process of rehabilitation again and emphasize that developments should be made urgently.

By comparison with the corporate rescue legislation in England and other jurisdictions, I try to make my proposal reasonable and practical. Before starting my proposal, I want to emphasize in advance that there is not any perfect corporate rescue legislation in the world. As Belcher observes: 'All rescue can be seen as, in some sense, partial.' (Note14) Different parties in a corporate rescue regime may have different perspectives of whether the rescue is "successful." Furthermore, it has been admitted that in the process of corporate rescue "a complete success might be thought to involve a restoration of the company to its former healthy state", (Note15) obviously in practice such kind of success is unlikely. Substantially, corporate rescue legislation is based on different historical social and cultural background of different countries. Any effort to enact a perfect corporate rescue legislation is vain, what we could do is try to make a better one but a best one.

\section{My Proposal}

\subsection{Try to Adopt a 'Middle-Way' in Control of the Company}

Simply speaking the objective of a rehabilitation procedure is to obtain more value than which might be obtained from the standard liquidation. (Note16) For a rehabilitation procedure to achieve this objective, one important point is to ensure the features of the procedure must be sufficiently attractive to encourage debtors to commence proceedings sufficiently early on when a company is in financial difficulties. Whether a company's financial distress could be early noticed is very important in the whole process of corporate rehabilitation regime, because that is the key to prevent financially viable firms to go into inefficient liquidation. It is also obvious that debtors of a company knows that he will lose the control of the company, lose his job and lose his wage if he exposes the 
financial difficulties of the company, how can you expect the debtors of the company will commence proceedings sufficiently early? Hence in the process of rehabilitating a company who will control the company is very crucial. Nearly every country has its own approach to this issue. The most different ones are the United Kingdom and the US who were noticed to stand at two ends of the spectrum. As regards two competing parties in corporate rescue regime - creditors and debtors, (Note17) the perspective of corporate rescue in England inclined to be punitive the wrongs and reward creditor. However in the US, the perspective of corporate rescue tended to rescue the failed and gave debtors a second chance.

Certainly, any firm conclusion of which regimes' approach is appropriate is an arbitrary or hasty conclusion, because every country has its own historical social and cultural differences. A commentator ever said that: "The different institutional and cultural make-up of the UK means that it would not be possible to "parachute" insolvency laws from another country and expect them to work in the same way." (Note18)

In England, when a company went into administration, the former management of an insolvent company is not usually allowed to remain in control. In English insolvency legislation when an administration order is in force "the affairs, business and property of the company shall be managed by a person ('the administrator') appointed for the purpose by the court." (Note19) The former management of an insolvent company is not usually allowed to remain in control. (Note20) The general view is that even where there is a likely rescue of the corporation or the business, an administrator should take over. Many opponents both in academic field and in practice criticized this approach. They hold the point that when comparing between allowing the former management team to remain in control with making an administrator takes over, they prefer the former. In order to emphasize the flaws of the approach in the England, they usually compare the differences between the administration in England and debtor-in-possession in the United States. They hold the viewpoint leaving the company in administrator's control is a costly and inefficient way. They argued that a management team who had already familiar with the company's business would be more likely to successfully reorganize firm in financial difficulties. More importantly, leaving the former management in control will encourage debtors to address their financial difficulties at an early stage, thereby increasing the chances of an effective rehabilitation. Indubitably, the American approach of "debtor in possession" (Note21) seems more reasonable and practical in view of the above reasons. However, in my view the American approach made a debtor nothing to lose but everything to gain when the company is in the process of rehabilitation. Although the debtor should be responsible for the rehabilitation proposal, that does not affect his substantial rights which means "debtor in possession" itself is also controversial. Furthermore, in England, bankers appeared to have acquired respectability over the centuries and they played a very important role in English economic development. "Insolvency practitioners also tend to work for the benefit of the creditors, especially the secured creditors, as opposed to debtors." (Note22) Considering the above reasons, any viewpoint which tended to enable the debtor to retain full control over the operation of the business as has been followed by the United States in England is impossible and impractical.

Obviously, no matter the administration in England or debtor in possession in the US, any approach has its own outstanding merits and inevitable flaws. In my view, a better proposal is to make a combination of the two approaches.

On the one hand, during the period of rehabilitating a company a debtor is permitted to continue to operate the enterprise. On the other hand a debtor's work should be under the close supervision of independent administrator. This administrator is appointed by or out of the Court. (Note23) He can be seen as an officer of the Court hence he will be subject to the court's supervision. No matter the administrator is appointed by the Court or out of court even though he is appointed by the holder of floating charge, he should work in the interests of the company's creditors as a whole. (Note24) This approach in one aspect can avoid a foreigner to operate the company. In another aspect it also reduces the chance of abuse by the debtor and protects the interest of creditors. More importantly, it ensures a more widely use of the rehabilitation process than the present one. In reality, many companies liquidated not because they do not want to be rescued but since they went into rehabilitation process too late. Due to various reasons debtors did not want to expose their financial distress until the company is too late to be rescued. That is an important reason why corporate rescue mechanism did not be widely used in the UK. Leaving the debtor in control of the company and with an administrator closely supervise his work will to some extent resolve this problem. Furthermore, with the debtor in a day-to-day possession, it will significantly reduce the judiciary cost, which makes the corporate rehabilitation procedure more efficient. Although some judiciary cost has to be paid for the administrator who worked as an officer of the Court, the spending is relatively lower.

Whether this approach can be successfully applied in practice is determined by the Court which means the Court should have specific provisions regarding the division of authority. For example, during this process what a 
debtor should do is to manage the company as usual and at the same time prepare a rehabilitation plan. This plan should be approved by the creditor committee. The administrator will closely supervise the work of a debtor. If the debtor violates his fiduciary duties during his management, the administrator can apply for the Court who has the authority to displace the debtor's management entirely.

\subsection{The Right to Initiate a Plan}

At the first sight, the suggest I proposed above is quite like the approach that adopted in Ireland. (Note25) However, after a careful comparison between the one I suggested and the one adopted in Ireland, you will find actually there is great difference between them. Firstly, let us have a general review of Irish corporate rescue legislation. The Irish legislation related to corporate rescue is mainly regulated in Irish Companies (Amendment) Act 1990. Irish Companies (Amendment) Act developed from a quite special background. It was introduced with an attempt to provide a rescue for one of Ireland's leading group of companies - Goodman which was in serious financial difficulties at that time. (Note26) In this urgent circumstance the main purpose of the Act was to rescue the Goodman to avoid it go to liquidation. Therefore, it is not astonishing that this new rescue mechanism developed in Ireland preferred to make a debtor still in control of the company although an Examiner is appointed by the court. However this urgent legislation cannot avoid the truth that in Ireland banks still have considerable economic and political power which will shape the overall direction of economic development. Therefore although debtors are in control of the company they do not have any substantial rights to formulate a re-organization plan. (Note27) This right is left to the examiners. As regards this point I do not quite agree with the Irish approach. In my view, in the process of rescuing a company, all relevant parties should be given a chance to make contributions to reorganization. The debtors are usually in the best position to determine what steps are necessary to make the enterprise viable again. Therefore, enabling them to prepare the plan may enhance the chances of successful rehabilitation.

The next question is should the right conferred to the debtor to initiate a plan is exclusive. As regards this issue, different jurisdictions have different approaches. In the US, the debtor has the exclusive right to reorganize the plan during a certain period. (Note28) At the expiration of this period creditors also have the right to propose a plan. Although in my view on this point the US approach seems more fair and efficient. I do not think it can be applied in the England. At least in the near future, it is impossible because banks in England still have 'supreme' powers. In this circumstance, giving debtors exclusive rights to initiate a plan is unrealistic. Considering the above reason, I suggest another approach instead of the above one. That is, on the one hand, debtors have the right to formulate a reorganization plan but this right is not exclusive. On the other hand, an administrator also has the right to organize a plan. Both of the plans have to be permitted by the creditor committee before it comes into force. I think this approach provides all the relative parties a chance to contribution and every party will have the incentive to try their best to rescue a company.

\subsection{From Rehabilitation to Liquidation}

We must recognize that although with the close supervision of administrator leaving the debtor in control will also cause great risk. (Note29) Hence in order to ensure that rehabilitation proceedings may not be abused by the debtor, it is important that the law provide a mechanism to make sure conversion from the rehabilitation proceedings into liquidation whenever the debtor has abused his power and violates his duties. In the US, once a court has noticed that the debtor did not act in good faith, it may shift decision-making authority from the debtor to an officer of the court, such as a trustee or an interim receiver. (Note30) "This displacement is often an intermediate step that leads quickly to the termination of the reorganization effort and the liquidation of the debtor." (Note31) The Approach adopted in the US provided us with a systematic framework. However, in my proposal I think there is one point needs to be changed. As I suggested above, administrator should closely supervise the debtor while he was in control of the company. Whenever the administrator find debtor violated his fiduciary duties, he can apply to the court for a removal of the debtor and the administrator will directly take possession of the company. This point is different from the American approach which after the displacement there is another officer be appointed. In my view this approach has two advantages. On the one hand, this approach can ensure while debtor is in control of the company, he can act in good faith. On the other hand, no alternative officer of the Court is appointed which will greatly reduce the cost of the procedure and seems more efficient.

Before ending this part, there is a crucial point which I want to emphasize. No matter administration in England or debtor- in-possession in the US or the model I suggested above, all of them are based on the fact that there is not an administrative receiver is appointed at that time. As I have explained in the first part that one great contribution of the Enterprise Act 2002 was that it terminated the right of a floating charge holder to appoint an administrative receiver. However, we should also notice that it still possible to appoint an administrative receiver 
in certain cases. (Note32) Beyond that the new legislation did not make any changes to the general law concerning the powers and duties of administrative receivers. In my view, terminating the floating charge holder's rights to appoint an administrative receiver absolutely is impossible and impractical. I never try to suggest that, however, in my view, the law concerning the powers and duties of a floating charge holder should be changed. He should not be only responsible for the floating charge holder but the interests of creditors as a whole. Comparing with recent development of the rescue culture in the UK which promoted a collective procedure, this provision deviated from the substance of the corporate rescue legislation. Hence a reform of it is necessary.

\subsection{Availability of Finance}

When a company enters into a formal insolvency process the difficulties of obtaining financing may increase considerably. (Note33) In one aspect, creditors do not think it is worthy to take risk to lend to a company whose "life" depends on the success of the proposed rescue. In another aspect, even if any "kind" creditors who would like to lend, the administrator will find there is no security to offer. (Note34) If there is not funding available all the rescue procedures will remain largely academic exercises. Many countries have realized that without finance a business will not be viable and hence a rescue will be failed. "Recently, as part of reform many countries have introduced the superiority of creditors." (Note35) "For example, in France and Germany all creditors providing goods and services after commencement of proceedings are priority creditors." (Note36) "In Sweden the debtor can raise super-priority financing subject to the agreement of the overseeing insolvency practitioner; and in Australia super-priority finance is available with the consent of secured creditors." (Note37) The most notable one is the US. In the US availability of finance through the provision of "Super Priority Financing" is thought to be most well developed strategy for super priority financing. Firstly, unlike in France and Germany, in the US once a debtor is in reorganization, the otherwise binding agreement of a supplier to furnish goods or services to the debtor on credit probably becomes unenforceable. (Note38) "The debtor has to pay in cash for goods, services, or the use of property provided after filing, even if the contract between the parties required that they be furnished on credit." (Note39) Secondly, in the U.S. corporate rescue legislation, credit extended to the debtor during reorganization has priority over pre-petition unsecured claims. (Note40) If the extension of credit is in the ordinary course of business, the priority is automatic; (Note41) if the extension is outside the ordinary course, the priority must be authorized by the court prior to the granting of credit. (Note42) Obviously, in the US there are not provisions authorizing the debtor to borrow on a secured basis. The reorganization lender ranks behind pre-reorganization security interests and ahead of pre-reorganization unsecured claims. (Note43) The US experience in this area is useful. Some aspects of it can be applied in the UK. Considering the supreme position of banks as the floating charge holders in the United Kingdom, they are the determinant about whether or not finance would be introduced. Obviously, banks are unwilling to allow additional finance to be introduced which has a priority over their own debt. The advantage of American approach lies at secured creditors will remain their priorities on existed security. Furthermore, this approach can ensure unsecured creditors or administrators does not lose anything, at least no worse than before lending of the credit. Hence everyone gains no one loses. In this circumstance the super-priority lending seems more acceptable. Actually the Insolvency Review Group in England has noted the advantages of the American approach and tries to introduce some basic principles of the US to the UK. (Note44) However until now this approach has not got any meaningful approval by the UK Government. (Note45) It is to be regretted that in the Insolvency Act 1986, the act fails to address the difficulty that an administrator may face in obtaining funding in the process of rehabilitation. More disappointedly, the proposal to allow for "superpriority financing" in the Enterprise Act 2002 was declined by the Government as well. Given the importance of new financing for a troubled enterprise during rehabilitation, it is very urgent that the English law gives the administrator adequate powers to obtain such financing. Certainly, I do not think it is appropriate to replicate Chapter 11 in the UK. However, the results of the "superpriority financing" regime adopted in the US should be closed monitored by the United Kingdom. At least, the basic principles underlying US practice should be suggested to the UK.

\section{Conclusion}

We have to admit that the corporate rescue legislation contained in the Insolvency Act 1986 to some extent is a failure. The Enterprise Act 2002 has greatly amended and developed the corporate rescue legislation in the UK. Whether those amendments will turn out to be more efficient than the existed procedures only time will tell. Due to the limits of my article, I only analysed a few points which I think need to be changed. Actually, there are many other aspects which need to be furthered amended, For example, the issue about company voluntary arrangements. In my view company voluntary arrangements is very important in the whole corporate rescue mechanism in the UK, because it aims to provide an easier and less costly way to rescue the company, which will especially benefit the small companies. Although the CVA provides us with a great expectation, in reality, its 
effect is disappointed. In future, for the purpose of ensuring corporate rescue mechanism can be widely used, CVA is an area which changes must to be done. Other problems about how to reduce the cost of the proceeding, how to curtail the length of it and how to make the rehabilitation more efficient also need to be further considered.

Corporate rescue should really be a culture in every country. Just like every patient has the right to be cured. Every company when it is expiring financial distress should be given a chance to be rescued. Corporate rescue should be encouraged because it could give everyone a hope, at the meanwhile, give the company a second chance to 'launch'.

\section{References}

Alice, B. (1997). Corporate Rescue. Sweet \& Maxwell, London.

Andrew, K., \& Peter, W. (2003). Insolvency Law—Corporate and Personal. Pearson Education Limited.

Gabriel, M. (1988). Chapter 11- An English Lawyers Critique. Insolvency Intelligence, 11(3).

Joseph E. Stiglitz. (1972). Some Aspects of the Pure Theory of Corporate Finance: Bankruptcies and Take-Overs. 3 BELL J. ECON. MGMT. SCI. 458.

Lo Pucki, \& George G. Triantis. (1994). A systems approach to comparing U.S. and Canadian Reorganization of financially distressed companies. Harvard International Law Journal.

Lynn, M. L., \& George, G. T. (1994). A systems approach to comparing US and Canadian reorganization of financially distressed companies. Harvard International Law Journal.

Michael, B., \& Michael, R. (1992). The Untenable Case for Chapter 11. Yale L. J., 1043, 1044.

Muir, H. (1999). The nature and functions of a rescue culture. JBL, 498.

Pont, G. D., \& Riggs, L. G. (1996). A principled Justification for Business Rescue Laws: A Comparative Perspective, Part II. International Insolvency Review 47. http://dx.doi.org/10.1002/iir.3940050104

Review Group (DTI, 200). (2000). Insolvency Service, A Review of Company Rescue and Business Reconstruction Mechanism.

Ron, W. H. (1997). Comparison of trends in national law: the pacific rim. Brooklyn Journal of International Law, 139.

Vanessa, F. (2002). Corporate Insolvency Law_Perspectives and Principles. Cambridge University Press.

\section{Notes}

Note 1. Lynn M. LoPucki and George G. Triantis " A systems approach to comparing US and Canadian reorganization of financially distressed companies" 1994 Harvard International Law Journal at p 267

Note 2. Insolvency Act 1986 Sched. B1, para. 2

Note 3. The same problem can also be found in other jurisdictions like the US and the Australia. For a further discussion about it please see G.Dal Pont and L. G Riggs, 'A principled Justification for Business Rescue Laws: A Comparative Perspective, Part II' (1996) 5 International Insolvency Review 47 at p76

Note 4. Andrew McKnight "The reform of corporate insolvency law in Great Britain-the Enterprise Bill"2002 JIBL 17(11) at $\mathrm{p} 325$

Note 5. Certainly, this is not the only element which made the UK rescue procedure costly. Other elements like the time limit of each procedure and the whole length of the proceeding; the complexity and uncertainty of the proceeding also make the UK rescue mechanism rarely used by small companies.

Note 6. Insolvency Act 1986 s250 (1) 72 A

Note 7. The same concern was expressed by Mr Andrew Campbell for International Corporate Rescue ( Semester Two 003/2004) at p 16

Note 8. Please see Andrew McKnight "The reform of corporate insolvency law in Great Britain-the Enterprise Bill"2002 JIBL 17(11) at $\mathrm{p} 332$

Note 9. Please see Andrew McKnight "The reform of corporate insolvency law in Great Britain-the Enterprise Bill'2002 JIBL 17(11) at $\mathrm{p} 332$

Note 10. Insolvency Act 1986 s250 (1) 72B -72H 
Note 11. Except under the new s. 176A of the 1986 Act. This point was criticized by Andrew McKnight in his article "The reform of corporate insolvency law in Great Britain-the Enterprise Bill"2002 JIBL 17(11) atp332

Note 12. See Sched. 6 of the Insolvency Act 1986.

Note 13. For example, in the annual report 2000 conducted by Department of Trade and Industry and HM Treasury, the review group suggested there should be clear legislation about availability of finance in the process of rehabilitation.

Note 14. See Alice Belcher, Corporate Rescue ( Sweet \& Maxwell, London,1997) at p.23

Note 15. Muir Hunter. "The nature and functions of a rescue culture" 1999 JBL at p 497

Note 16. Ron W. Harmer in his article "Comparison of trends in national law: the pacific rim" 1997 Brooklyn Journal of International Law at p 145 provided a more explicit explanation about the aim of corporate rescue generally.

Note 17. Such kind of interpretation of how to distinguish corporate rescue jurisdictions was expressed by Muir Hunter in his article "The nature and functions of a rescue culture" 1999 JBL at p498

Note 18. Ron W. Harmer “ Comparison of trends in national law: the pacific rim”(1997) 23 Brooklyn Journal of International Law 139 at $\mathrm{p} 140$

Note 19. s.8(2) of the Insolvency Act 1986 , with the Enterprise Act 2002 came into force a administrator can also be appointed out of court

Note 20. Although the legislation clearly provides for a company's management to be able to be kept in place by an administrator, this seems rare in practice

Note 21. Debtor in possession was regulated in the US rescue legislation- Chapter 11.For further comments about the Chapter 11 please See Michael Bradley \& Michael Rosenzweig, " The Untenable Case for Chapter 11,” 101 Yale L.J. 1043, 1044 (1992); Lynn M. LoPucki \& George G. Triantis, “ A Systems Approach to Comparing U.S. and Canadian Reorganization of Financially Distressed Companies," 35 Harv. Int'l L.J. 267, 305 (1994). These two articles demonstrate another viewpoint about the Chapter 11.

Note 22. Gabriel Moss “Chapter 11- An English Lawyers Critique” 1998 Insolvency Intelligence11(3) at p 18

Note 23. As amended in Sched. B1, para. 4.in Enterprise Act 2002

Note 24. This point will be developed further on in my proposal

Note 25. Irish Companies (Amendment) Act 1990

Note 26. For a detailed introduction about the background of Irish Companies (Amendment) Act 1990 please see the handout of Mr Andrew Campbell for International Corporate Rescue ( Semester Two 003/2004) at p 22

Note 27. "Peter Fitzpatrick, who was the examiner for sixty one of the companies within the Goodman International Group, describes the role of the examiner as that of an investigating accountant." Cited from the handout of Mr Andrew Campbell for International Corporate Rescue ( Semester Two 003/2004) at p 22

Note 28. In the US this period is 120 days.

Note 29. For further commentary about this issue please see Joseph E. Stiglitz, Some Aspects of the Pure Theory of Corporate Finance: Bankruptcies and Take-Overs, 3 BELL J. ECON. MGMT. SCI. 458 (1972)

Note 30. Bankruptcy Code $\S 1104(a)$.

Note 31. "If a trustee is appointed in a U.S. reorganization, there is a substantial likelihood that the trustee will terminate the business operations or that the case will be converted to Chapter 7" cited from LoPucki and George G. Triantis " A systems approach to comparing U.S. and Canadian Reorganization of financially distressed companies" (1994)Harvard International Law Journal at p303

Note 32 . These cases are usually n relation to capital markets and certain other high value transactions and under certain types of financial markets' security. For a detailed legislation about this issue please see Enterprise Act 2002 S250(1) $72 \mathrm{~A}-72 \mathrm{H}$

Note 33. R3's Ninth Survey of 2001 indicated that in one in five cases of failed companies with in excess of $£ 5 \mathrm{~m}$ turnover, the main factor prevent in a positive outcome was lack of funding.

Note 34. Mr Andrew McKnight ever said in one of his article that: "the difficulties that an administrator may face is obtaining funding is usually in a situation where it would be desirable for him to be able to offer security but, at the time of his appointment, the assets of the company were already subject to fixed security or were 
subject to a negative pledge preventing the company from granting security over the assets. Furthermore there is no provision which would allow the administrator to proceed in a manner which may be contrary to or affect the rights of such a person and ,being an officer of the court, he must act honorably towards such a person" cited from article "The Reform of Corporate Insolvency Law in Great Britain-The Enterprise Bill"2002 JIBL 17(11) at $\mathrm{p} 328$

Note 35. Insolvency Service, A Review of Company Rescue and Business Reconstruction Mechanism, Report by the Review Group( DTI,200)('IS 2000)at p40

Note 36. See footnote 34

Note 37. See footnote 34

Note 38. This assertion is based on Bankruptcy Code $\S 365(\mathrm{c})(2)$, which provides that "the trustee may not assume ... any executory contract ... if such contract is a contract to make a loan, or extend other debt financing or financial accommodations...."

Note 39. BIA § 65.1(4).

Note 40. Bankruptcy Code s 364

Note 41. Bankruptcy Code $\S 364($ a)

Note 42. Bankruptcy Code $\S 364$ (b).

Note 43. Bankruptcy Code $\S 364(d)$.

Note 44. Please see Insolvency Service, A Review of Company Rescue and Business Reconstruction Mechanism, Report by the Review Group( DTI,200)('IS 2000) at pp.33-35

Note 45. The Government hold the point that: Firstly, Unlike in the US where there is not any equivalent to floating charge in the United Kingdom the prevalence of the floating charge meant that uncharged assets were rare in corporate insolvencies. Secondly, it had to be faced that "if the rehabilitation of the company eventually failed, the super-priority funding would operate at the expense of other creditors." 